\title{
Comparative Analysis of Unmanned Aircraft Regulations for The Development Of Startups
}

\author{
Thiago de Souza Beté ${ }^{1 *}$, José Eduardo Storópoli ${ }^{1}$, Heidy Rodriguez Ramos ${ }^{1}$, Diego de Melo Conti ${ }^{2}$, \\ Cristiano Capellani Quaresma ${ }^{1}$ and Edson Aparecida de Araújo Querido Oliveira ${ }^{3}$
}

\begin{abstract}
This article provides a comparative analysis of unmanned aircraft flight regulatory documents to assist and support the construction and development of technology and innovation startups around unmanned aircraft in smart cities. The identification of the main research factor is based on countries with academic scientific production using the database of the Web of Science (WOS) platform. In summary of the results and contributions, a regulatory view and the non-standardization of documents between the countries that present the future trends for the sector was evidenced.
\end{abstract}

Keywords: Comparative analysis; Innovation; Smart Cities; Startups; Technology; Unmanned aircraft; Web of Science

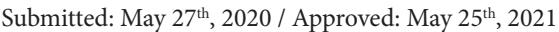

\section{Introduction}

The world is undergoing a technological and innovative revolution in aviation and it is estimated that in the coming decades unmanned aircraft operations will surpass manned aircraft operations (Hodgkinson \& Johnston, 2018). Liu, Peng, Wang, Xu, and Guo (2019) all state that operating with unmanned aircraft in cities combines new technologies that meet the demands of citizens and assign planning models for the development and prosperous growth of cities. This line of technological advances with the adoption of practices and governance generates efficiency in the services provided (Molin, 2017).

The Unmanned aircraft is one of the innovative technologies added in cities that allows applications and solutions in new management models in cities. The operation of unmanned aircraft applied with digital, spectral cameras, monitoring sensors and devices, is transporting cargo and people, and can be applicable to the management and governance of a city (Raparelli \& Bajocco, 2019). Cândido, Silva and Paranhos (2016) and Oliveira, Pantoja and Brisola (2016) all state that the growth and development of a city can be operated with the innovation of a management tool. The remote sensing can obtain aerial images for geographic analysis, ecological and sustainable the search for new processes and procedures based on efficiency in cities.

A large part of this rhythm is recorded on the internet channel You Tube.com, founded in 2005, which allows access to publications of videos and images that show the action or effect of referring or narrating the event that was often not scientifically studied (Manuella, 2016). Videos of unmanned aircraft can be viewed, flying in different sectors of agriculture, livestock, industry, energy, aerospace, security, forestry, logistics, photography, real estate, monitoring of structures, cartography, surveillance, monitoring of hurricanes and terrestrial climate, rescue in disasters and accidents, fighting fires, platform inspections, border patrol, land, farms, sites and cities, it helps people with greater needs in places of difficult access or wilderness, in addition to the mobility of transporting cargo and people from whom this all represents that unmanned aircraft has enormous potential for expansion and use in more sectors on the planet.

Given the opportunities that innovation and technology transforms and creates the unmanned aircraft market in cities, it also associates the "innovation shock" with the concept of introducing new products and services that stimulates and accelerates the demand and evolution of technologies (Argyres, Bigelow \& Nickerson, 2015). In recent years, startups have become popular and based on a good base of concepts and operational regulations in several sectors. Aulet (2013) and Picken (2017) all state that the process of creating and developing a Startups emphasizes in disciplines of processes of exploration, validation and refinement of the business project. Blank (2017, p. 12) Startups need to continue to invent and innovate continuously to ensure the growth and survival of the business model.

Startups are fundamental to the economic development of a city and social welfare (Mack \& Mayer, 2015). They have the capacity for innovation and consequently the breaking of traditional business models, job creation and transformation of the industry (Finger \& Samwer, 1998). In view of this information, the operation of an unmanned aircraft requires aerial security to certify the safety of aircraft operation when applied to the business models of products and services in any sector in a city.

Aviation security was born with regulations and legislation. Be it for manned aircraft at the beginning of the century, as well as for unmanned aircraft today. The regulatory evolution occurred due to the need to maintain security at an adequate level (Weber, 2017). The standardization of rules refers to the safety of people's lives and injuries due to accidents and incidents. Each nation is sovereign and is responsible for standardized structuring, legislation and regulation.

(1) Program master in Smart and Sustainable Cities (PPG-CIS), Nove de Julho University - UNINOVE, São Paulo, SP, Brazil.

(2) Program master in Sustainability, Pontifical Catholic University of Campinas, Campinas, SP, Brazil.

(3) Program master's in Planning and Regional Development at the University of Taubaté, Taubaté, SP, Brazil.

${ }^{*}$ Corresponding author: thiago.souza.bete@gmail.com. 
Valavanis and Kontitsis (2007) and Blom (2010) all state that the regulation of unmanned aircraft in the military sector is explored. Wagner (2015) With the civil sector, there are legislative, regulatory and governance impediments to application and operation. Many cities already apply activities with unmanned aircraft (Kaleem, Rehmani, Ahmed, Jamalipour, Rodrigues, Moustafa and Guibene, 2018; Lai. H, Lai. Y, Lan, Lin and Ho, 2018 \& Dung and Rohacs, 2018). However, it does not mean that a detailed and standardized regulation is included that aggregates all cities (Wagner, 2015).

In principle, the rules governing manned aircraft are in accordance with the International Civil Aviation Organization (ICAO) established in the Chicago Convention of 1944. With this minimum regulation, each State must authorize its operation. And application of detection and tracking technologies, to prevent accidents and incidents. With the application of regulations, cities acquire governance experiences with a view to the future the law to Civil, criminal and administrative legislation regarding the inviolability of intimacy, honor, image and the private life of people in cities.

To emphasize the importance of regulating unmanned aircraft, for various sectors with startups, this study will be exploratory on the terminological, operational concept and a comparative analysis of regulations. The purpose is to ascertain the regulatory variables for providing an overview of each country, enabling regulatory analysis of the past and present, in addition to allowing for future trends in the world.

\section{Literature revision}

The actual term to be defined for an unmanned aircraft has undergone several changes over time (Blom, 2010). Mrva (2017) contemplates that now there are many terms and abbreviations about the real definition or the real term for unmanned aircraft of which few countries have defined the real function. Although systems and unmanned aircraft have evolved in recent decades, their design has remained the same, but their nomenclature has not (Watts, Ambrosia \& Hinkley, 2012). Started with military activities, today we have application for civil activities, of which the terms and acronyms operate: Drones; Remotely Piloted Aircraft (RPA); Remotely Piloted Aircraft Systems (RPAS); Unmanned Aircraft (UA) and Unmanned Aircraft System (UAS).

\subsection{Drones}

The designation of the word "Drone" is a term originated in the United States of America, which has been widely publicized as any flying object that is not manned (Pecharromán \& Veiga, 2019). Mrva (2017) already considers it as an unmanned machine, whether in water, on land, in the air or in space, regardless of its purpose, be it professional, for recreational, commercial or military use. The term drone was created by the US military from the 1940s, but with the update of the term over time, it fell due to the mission and operation of the aircraft, as they were updated according to the technology of the time (Blom, 2010 ). The term "Drone" has no parameters or legal technical support in regulatory laws in any country (Pecharromán \& Veiga, 2019).

\subsection{Remotely Piloted Aircraft (RPA) and Remotely Piloted Air- craft Systems (RPAS)}

The term Remotely Piloted Aircraft (RPA) had its originated in the 60 's by the American military (Blom, 2010). And it can also be inappropriate, because for many, the aircraft is not piloted, but "autonomous” (Mrva, 2017). Mrva (2017) and Pecharromán and Veiga (2019) consider that there are two types of RPA, one remotely controlled and the other autonomous.

Controlled RPA, that is, remotely piloted, is the aircraft from which the pilot is not on board, but that his pilot or operator maintains remote control of the air or the ground (Mrva, 2017). They can also use interfaces such as computers and simulators outside of RPA in flight (Pecharromán \& Veiga, 2019). Pecharromán and Veiga (2019) and Mrva (2017) all state that the autonomous RPA has its operation of which there is no human element in the operation of the flights.

Mrva (2017) considers that the issue in defining the automation of these aircraft is that there is no clear dividing line in the scientific environment that determines whether the aircraft is autonomous or still receives information from its controller or programmer before, during or after the flight. The term is considered by Blom (2010) problematic because when it was contemplated they made flights in aircraft with pre-programmed missions during which the aircraft had no pilot, but there was also no controller or operator, that is, they were not being remotely piloted.

The term Remotely Piloted Aircraft Systems (RPAS) is the system of an RPA, when applied, any type of system resource that makes the aircraft fly, such as the remote piloting station and the control command accesses (Pecharromán \& Veiga, 2019). It can also be adopted as a system, the pilot and any other component that is specified in the aircraft design, for its healthy operation.

\subsection{Unmanned Aircraft (UA) and Unmanned Aircraft System (UAS)}

The term Unmanned Aircraft (UA) has the same concept as the term Remotely Piloted Aircraft (RPA) according to Advisory Circular No. AC-91-FS-2015-31 (2015). The Dictionary of Military and Associated Terms, DoD, U. S. (2019) applies the term Unmanned Aircraft (UA) for is "Aircraft that does not carry a human operator and is capable of flying with or without a human remote control"

Gupta, Ghonge and Jawandhiya (2013) states that the applicability of an Unmanned Aircraft (UA) is that of an aircraft that does not contemplate a pilot on board, but that is controlled via the ground system or flying autonomously based on routes and flight planning pre-programmed, but carrying loads such as low and high resolution cameras, reconnaissance videos or any non-lethal cargo. Lethal charges such as weapons, bombs or missiles can be applied to military terms with acronyms: Uninhabited Air Vehicle (UAV), Unmanned Air Vehicle (UAV), Unmanned Aeronautics Vehicle (UAV) and Unmanned Aerial Vehicle (UAV).

Gupta, Ghonge and Jawandhiya (2013) and Watts, Ambrosia and Hinkley (2012) all state that UA or RPA can be classified as fixed wing 
or rotary wing aircraft. Fixed wing aircraft refer to models with wings which require a runway or catapult to launch and fly at high cruising speeds, in addition to high altitudes. Rotating wing aircraft refer to models that do not have wings but have a rotor and propeller system like the helicopter and fly at low cruising speeds, in addition to low altitudes.

The Term Unmanned Aircraft System (UAS) in the same conception as the term Remotely Piloted Aircraft Systems (RPAS) (Advisory Circular $n^{\circ}$ AC-91-FS-2015-31, 2015). The Dictionary of Military and Associated Terms, DoD, U. S. (2019) has the term Unmanned Aircraft System (UAS) as a "System whose components include the equipment, network and personnel necessary to control an unmanned aircraft". Gupta, Ghonge and Jawandhiya (2013) and Watts, Ambrosia and Hinkley (2012) affirm that the pilot only controls the aircraft by means of a cabin on the ground, but that, in the absence of this, the operator has to take control, of the aircraft in three different ways, that is, flying remotely, semi-autonomously and autonomously

\subsection{Civil operation of unmanned aircraft.}

The regulation of unmanned aircraft for operation is subject to the provision of the International Civil Aviation Organization (ICAO) with DOC 7300/9 (2006). Its eighth article provides that "Each Contracting State undertakes to ensure that the flights of these pilotless aircraft in regions open to civilian aircraft are controlled in order to avoid any danger to the others". In the case of minimum security standards required, each State should regulate its laws and regulations based on the ICAO annexes, as well as: Annex 1 (2018) Personnel License; Annex 5 (2010) Units of Measure; Annex 6 (2016) Aircraft Operations; Annex 7 (2012) Nationality and Registration Marks and Annex 8 (2005) Airworthiness.

ICAO (2020) adopts that States also consider their terms as Drone, UA or RPA with assessments adopted for their suitability. The definition of regulatory requirements is about the risk approach study, which is based on the size of the aircraft and its performance. The performance is aimed at achieving the expected result of what the machine offers for the operation with the proper safety in the operation, for the operator and the consenting parties. The risk-based approach focuses on two types of risk: from causing fatality and damaging properties. The risk category includes aircraft size, low flight altitude, aircraft line of sight in clear daytime conditions and specific distances from consenting persons, buildings and airports (ICAO, 2020).

Annex 5 (2010) standardizes the measures when it comes to the size of the unmanned aircraft whose physical characteristics are by mass, standardized in (KG) kilograms; altitude is measured in feet ( $\mathrm{ft})$ when applied to the operational flight ceiling and height is measured in meters (m) when applied to consenting persons. Annex 6 (2016) standardizes the flight operation, of which ICAO (2020) considers that the proximity of airports and areas populated with consenting persons can influence the likelihood of injuring people, causing fatality and damage to other aircraft or properties. The risk categorization of each State, with the components of the categorization scheme, must be limited since there are aircraft that present the minimum risk if the size and operation are analyzed, which can be classified as a low risk category, regulated minimal risk category and regulated acceptable risk category, of which each State will regulate. The ICAO (2020) recommends that the low risk category can fit into operations that have specific conditions, from which they can operate without the authorization of the regulatory authority, such as day flights in Visual Line of Sight (VLOS) operations, away from consenting persons, buildings and airports, at a maximum altitude, in controlled and unrestricted airspace and their performance limitations.

In the regulated minimal risk category, VLOS operations are recommended, with light weight aircraft, with height and altitude limitations, that pilots or operators must be have a requirement basic they aviation knowledge and aircraft must be have simple identification requirements. In the regulated acceptable risk category, VLOS, Extended Visual Line of Sight (EVLOS) and Beyond Visual Line of Sight (BVLOS) operations are recommended, operating aircraft with a higher weight, with load capacity, requiring a more limited regulation with restrictions or prohibitions of zones and areas, in addition to the requirements required of the pilot or operator and the aircraft and its operation.

The term VLOS is a flight operation in "Visual Line of Sight" from which one has the actual flight condition with the visual meteorological conditions (VMC) to safely operate the aircraft in flight, without the need for equipment and human assistance. The term EVLOS means that the aircraft is in VMC flight operation, without the aid of equipment, but requiring human support. The term BVLOS means a flight operation beyond the visual line of sight, that is, when the aircraft is not seen and the flight conditions are below the minimum (VMC), requiring the aid of equipment and human. The operation is also managed and adequate to ensure the safety of the flight, of which the State authority can certify the operator and pilots according to the annexes.

Annex 1 (2018) regulates Personnel Licensing, from which pilots or operators receive appropriate licenses, which include specific training, tests, medical examinations and which meet the minimum age requirements for flight operation.

Appendix 7 (2012) regulates Aircraft Nationality and Registration Marks, from which aircraft receive the appropriate registration and State mark, so that the operator or the owner receives an aircraft registration certificate.

Annex 8 (2005) regulates Airworthiness of Aircraft, which transmits the safety of the design, construction, maintenance and continued operation, within the manufacturer's conformity, so that the operator or owner receives a certificate airworthiness.

ICAO (2020) also recommends the assessment of operational risk by the operator and the pilot, with the objective of mitigating risks within the operating scenarios, from which the person in charge of the operation is responsible, to be aware of the limitations, specifications and aircraft capacity with safety and insurance 
contingency procedures in cases of accidents and incidents. Finally, the State authority, recommended by ICAO, needs to determine in the authorization of special flight in operations with unmanned aircraft the limits regulated in the others: "Annex 02" Rules of the Air; "Annex 03" Meteorological Service; "Annex 04" Aeronautical Charts; "Annex 09" Facilitation; "Annex 10" Aeronautical Telecommunications; "Annex 11" Air traffic services; "Annex 12" search and rescue; "Annex 13" investigations of aeronautical accidents and incidents; "Annex 14" Aerodromes; "Annex 15" aeronautical information; "Annex 16 " protection of the environment; "Annex 17" security against unlawful interference; "Annex 18" transport of dangerous cargo; "Annex 19" management of operational security.

\section{Method}

The present study includes a short summary of multiple sources related to legislation and governance related to unmanned aircraft. Nunes, Nascimento and Alencar (2016) all state that this point, the research applies a synthesis of existing and exploratory facts from the real context on the topic and the study process does not interfere with the facts described. Koche (2011), (2016) and Hair, Babin, Money and Samouel (2005) claim that the exploratory study complements the identification and exploration of numerous variable investigations.

Stocker, Bennett, Nex, Gerke and Zevenbergen (2017) state that the point-to-point comparison methodology attributes the variables to a set of criteria that they consider to be the main regulatory aspects of unmanned aircraft. The criteria and variables are approaches based on a regulatory review process, from which they provide an overview of the regulatory approaches and characteristics of unmanned aircraft from the past, the present and which allows to carry out future trends. The theoretical framework is reviewed from the terminological point of view, which is considered a revised literature for legal considerations of the regulations.

\subsection{Data base}

The present literature review is composed of the facts related to the nomenclature and the regulations recommended by the International Civil Aviation Organization (ICAO) for the operation of unmanned aircraft.

The legal guidelines are represented by the syntheses of the documentation that regulate the operations of unmanned aircraft in the current civil sector, be they regulations, legislation and governance of countries ahead of scientific academic productions according to the bibliographic research conducted in April 2019, from which the Web of Science (WoS) database was used as a reference source.

The search using the term "Unmanned Aerial Vehicle" (UAV), refined by the word "Cit*", found 322 documents related to the topic. With the refinement of the WoS "filter", only peer review was chosen and was limited to 166 journals, excluding books, conferences and or congresses. As it deals with a new technological and innovator concept and in integration in the cities, all areas of research and studies were maintained within the 166 peer review found between the years 2008 until April 2019. In total, 25 countries were included in the regulatory document comparison analysis found in WoS: Germany, Saudi Arabia, Australia, Austria, Belgium, Brazil, Canada, China, South Korea, Denmark, Spain, United States, France, Greece, India, England, Israel, Italy, Japan, Malaysia, Norway, the Netherlands, Russia, Taiwan and Turkey.

For a reliability of the research database, the first step was to relate the search of the governmental authorities that regulate the aviation of the countries analyzed to actually find the most updated documents when it comes to the operation of unmanned aircraft. All surveys were covered online on their respective websites related to the civil aviation authorities of the countries analyzed. However, the first search-related clash was the translation of websites related to aviation authorities and for that reason "Chrome" was used as an internet browser because it allows having a "Google" resource to translate "Web" pages in order to facilitate the reading and understanding of the studied content.

Within the languages found in each country, Mandarin languages were identified in the countries of China and Taiwan, in Spanish in Spain, English in Australia, Canada, the United States, India and England, French in France, Belgium and Canada, Russian in Russia, Arabic in Saudi Arabia, German in Germany, Austria and Belgium, Portuguese in Brazil, Korean in South Korea, Danish in Denmark, Greek in Greece, Hebrew in Israel, Italian in Italy, Japanese in Japan, Malay in Malaysia, Norwegian in Norway, Dutch in the Netherlands and Turkish in Turkey. Result of the restrictions on language translation by the documentation, unmanned aircraft sources and online databases from relevant international organizations were also compiled. Appendix 1 corresponds to the list of collaborative organizations with the regulations of unmanned aircraft worldwide, of which provide a short description of the content of the main existing regulations of unmanned aircraft.

\subsection{Research and data processing}

The exploratory study in a comparison analysis is a general method, from which two or multiple samples are compared in a relation ( $\mathrm{Li}$ jphart, 1971). The purpose of the comparison analysis is in the context of unmanned aircraft regulations, to identify commonalities and differences between the regulations. After the initial survey of authorities and the respective updated regulatory documents of the countries studied, a comparative analysis is carried out between the existing documents, which is guided by the methodological concept (Stocker, Bennett, Nex, Gerke \& Zevenbergen, 2017).

The criteria evaluated and established with the respective comparison variables, resulted in three in total, being: 1) Classification, 2) Operator or pilot and 3) Operation of unmanned aircraft as shown in table 1. 
Table 1. Comparative analysis criteria and variables.

\begin{tabular}{cll}
\hline Number & Criterion & Variables \\
\hline 1 & Classification & Term, Operation, Flight Ceiling, Class and Maximum Takeoff Weight. \\
\hline 2 & Operator or Pilot & Age, License, People and Airports. \\
\hline 3 & Operation & Registration of pilots and operators, Aircraft registration, Airworthiness Certificate (CA) and Insurance \\
\hline
\end{tabular}

Source: Prepared by the author (2020).

The variables refer to the proposed classification of the aircraft according to each regulation from which it will be highlighted in table 2:

Table 2. Classification of variables.

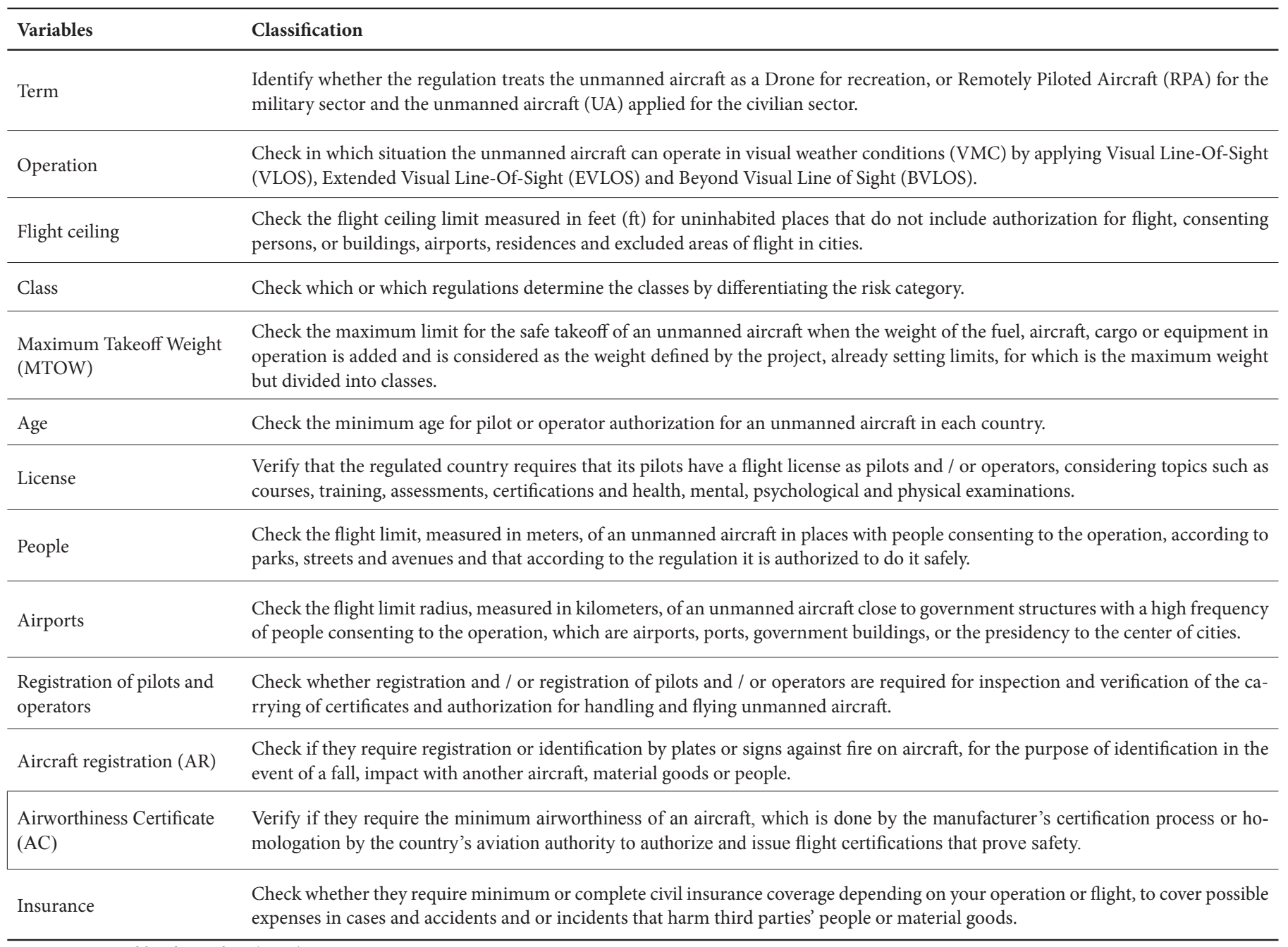

Source: Prepared by the author (2020).

\section{Results and discussion}

For regulatory analysis, existing and current regulations of the countries considered will be reviewed and compared: Germany, Saudi Arabia, Australia, Austria, Belgium, Brazil, Canada, China, South Korea, Denmark, Spain, United States, France, Greece, India, England, Israel, Italy, Japan, Malaysia, Norway, the Netherlands, Russia, Taiwan and Turkey. The Joint
Authorities for Rulemaking on Unmanned Systems [JARUS] (2020) is a group of experts from aviation security authorities and organizations and considers that since 2014 there has been a strong political call for the development of regulations for unmanned aircraft around the world. The European Union Aviation Safety Agency [EASA] (2020) was chosen at the request of the European Commission to develop a regulatory framework for unmanned aircraft operations and their systems. 
The objective is to maintain security within the cities of the countries of the European Union. Establish and study security issues to be made available among institutions, organizations and Member States. EASA works together and supports Supporting European Aviation [EUROCONTROL] (2020) which is a pan-European civil-military organization dedicated to supporting European aviation, whether manned or unmanned.

Worldwide cooperation also extends with the International Civil Aviation Organization [ICAO] (2020), which is a specialized agency of the United Nations (UN) that includes studies and analyzes for the development of policies and standards for improving safety world airline.

The Global Drone Regulations Database [GDRD] (2020) which consists of a database composed of a directory of countries with summaries of the main laws for drones and unmanned aircraft. JARUS has the objective of integrating technical safety requirements and operational certification of unmanned aircraft systems within airspace, to facilitate the authorities to write their regulations and their own requirements, avoiding varied or duplicate efforts in the country the country.

Appendix 2 shows the countries included in the analysis, which are part of the ICAO membership, except for Taiwan, which does not apply. In addition to the performance of countries in EASA with bilateral agreements, memoranda of understanding, technical cooperation, work arrangements and members.

Since the early 2000s, many countries have gradually begun to establish legal and regulatory frameworks for the commercial operation of unmanned aircraft, with a differentiation between recreational and professional or commercial flights, which provide a remunerated service with the operation of a unmanned aircraft in the environment in which we live in cities.

The purpose and importance of such regulation is to have a common purpose in relation to minimizing the risks to the operation, whether for users, for consenting persons, of whom they do not know about the flight operation of the unmanned aircraft, the airspace, security against terrorism, property and land, as well as other risks present in specific regulations of each country. This all fosters the market, industry and the future development of cities, especially with Startups.

Within the scope of the study, it was understood that the terms drone, UA and RPA are applied according to the demand and need of the countries. The application of the term drone in countries such as South Korea, Israel, Russia and Taiwan, has a more closed regulation, which does not apply the requirements to its operation and to only allow the VLOS flight, and to keep most of its territory with no-go zones. The countries that present with the term RPA, are regulated or contemplated of regulations coming from the military sector, but that have not been updated for the civil sector with the format UA, of which there is a rule, more specific regulations such as what can and cannot can fly in operation.
The flight condition VLOS, EVLOS and BVLOS is given to the limit that countries authorize the flight operation by the operational horizontal distance. Only Brazil, China, Denmark, Spain, Greece, Italy, Norway and Turkey, maintain freedom in all operations, as it is understood that the applied technology is safe and does not present risks in cities for such regulation authorization. Regarding the operational ceiling, there is a consensus among the countries studied, that the safe height for flights is $400 \mathrm{ft}$ or 120 meters, varying more or less, according to the need in uninhabited places or without consenting persons, or people who do not know the operation or do not know about the flights. The exception is for unmanned aircraft at the service of governments, city halls and municipalities.

The classification of unmanned aircraft is also a consensus among the countries studied, maintaining the (MTOW) limit. The maximum weight allowed that the country authorizes a commercial flight to obtain financial gains. When considering the conditions of free flights BVLOS, we have only Turkey, Brazil, China and Norway, which maintain the autonomy of aircraft with unlimited weight prescribed in the regulations if they have authorization from the authority. For those countries it maintains, the unlimited MTOW can be considered promising technological study countries for the evolution of unmanned aircraft, because with these characteristics, the industrial sector with startups has more autonomy to test new projects. The China that maintains and is the only country included in the study that already regulates UAS Agricultural and UAS Airship weighing more than 5,000 kilograms for the civil sector.

The analysis of operator or pilot was limited to classifying the minimum age of the pilot, of whom the responsibility would be contemplated, his license, certification, health and qualification, in addition to the prohibition of flying over public places with consenting persons, or close to places with high levels of traffic of consenting persons such as airports. In principle, many countries maintain the rule of civil majority within 18 years of age, to relate the condition of responsibility for the operation and the requirement for training with the license for complex operations required in the ICAO annexes.

Countries, which maintain freedom for operators or pilots under 18, ranging from 12, 14 and 16 years, such as Turkey, France, Denmark, Canada, Belgium, Austria, Australia, Norway, India and the United States allow the operation of flights less complex, but aiming that the responsibility always falls to the owner or operator with civil majority, in addition to the limitation and requirement of pilot licenses required in each country through the ICAO Annexes.

Regarding the concern of overflight in public places with environments with consenting persons, it is a consensus among countries to maintain a minimum height, of which they vary from 30 to 250 meters in height when applicable. Russia, India, South Korea and China prohibit the operation. Among the regulations, which require a minimum distance of 1.5 kilometers as required by Germany to up to 10 kilometers required by France, there is an emphasis on countries like Russia, China and Taiwan that completely prohibit overflights in 
prohibited areas. Regarding the analysis of the operation, with registration of the pilot or operator, there is a consensus among the countries analyzed that in more complex operations, it should be mandatory to record the operation, simply because it tracks the pilot and or operator in cases of accidents and incidents.

However, this is not the case with the mandatory registration required on aircraft, something like the prefix of an aircraft or the license plate of an automobile, as it is only allowed to put an identification tag. Australia, Austria and Norway, unlike the label, is obliged to put a fire nameplate, as it has the dynamics to resist fire itself in cases of accidents and incidents, for such an investigation proposed by each authority that requires such identification.

The Airworthiness Certificate is necessary and mandatory in most cases of highly complex flight operations, in addition to the requirement of the manufacturing certificate itself, from which the manufacturing company proves the operability of the unmanned aircraft and that the operator performs the required maintenance. by the manufacturer as scheduled, something that happens with manned aviation.

The mandatory minimum insurance for protection due to accidents and or incidents is necessary and mandatory for highly complex flight operations, limited only as an option to countries like Australia, Canada and Russia for commercial operations with financial gains, but understanding that in everyone, the responsibility remains with the operator or pilot with civil and criminal majority according to the legislation of each country and the registration made.

Appendix 3 presents the comparison of unmanned aircraft regulations, country by country, with all classifications determined in the methodology.

\section{Conclusion}

It is noticeable that despite the 25 countries found in the WoS for the analysis of regulatory comparison, they are producers of scientific studies with the theme unmanned aircraft in cities, these countries do not obtain from standardized regulations or referenced correctly. Each country maintains the legislation and regulations for the operation of unmanned aircraft specific to the degree of risk, which each State understands and considers as the operation and technology of that country to mitigate the risk. The updating or standardization of regulations between countries does not occur, as applications, operations and aircraft are varied complements based on the need and the extent to which the technology is available in the regulatory country.

For this reason, a Startups and companies, needing to invest in projects, products or services with unmanned aircraft, should understand and follow the rules and regulations of each country, with some, with little freedom and the others with more freedom. China already authorizes aircraft with more than 5,000 kilograms and are certainly the leaders in scientific research. They are the leaders and producers of aircraft technology, envisaged in the regulations, both for agriculture and for unmanned airships. This is proof that other countries need to review their governance, to the point of encouraging industry, commerce, goods and services, with Startups to start projects.

In this same conception, countries like Australia, Brazil, China, India, England and Turkey already have in the regulation the predictability of operations with unmanned aircraft with unlimited MTOW, if there is authorization from the authority. Proven by the comparative analysis and the date of issuance of regulations such as Australia and England in 2019, India in 2018, Brazil and Turkey in 2017 and China in 2015 , the most recent of those analyzed is considered.

As for European countries, it is understood that the regulation is limited to 150 kilograms, with the exception of England, as the authorities follow the legislation of the European Union Aviation Safety Agency (EASA) to maintain security within the cities of the countries of the European Union, but who intend to update their regulations, having as a standard expected in the year 2020. Also, there are difficulties, for a regulatory standardization of unmanned aircraft, that countries such as Israel, South Korea and Japan face obstacles as areas of maximum prohibition in their territories, due to internal and external military conflicts. We can conclude that countries like Russia, India, South Korea and the Netherlands, maintain ideas, concepts and the governance of a past regulation. Countries like Canada, Taiwan and the United States, England, Australia, Saudi Arabia and Malaysia, maintain the current regulation, present, but with little freedom. Countries like Spain, Austria, Germany, France, Denmark, Italy, Belgium and Greece, keep the current regulation, present, but the concept limited.

China, Brazil, Turkey and Norway, for maintaining a more comprehensive legislation with the current reality, demonstrated by the freedom of flight operation, the limits subdivided in the classification on the risks that it allows and the required security processes. These are the countries that have made the most progress in terms of regulation, from which they present the trends of the future and that seek to transform their cities into smarter cities, through the development, operation and application of unmanned aircraft, of which many Startups, companies and public authorities can benefit.

\section{References}

Advisory Circular no AC-91-FS-2015-31, December 31, 2015. (2015, December 31).China. UAS Regulations, Flight Standards Division of Civil Aviation Administration of China, Civil Aviation Administration of China, CAAC. Retrieved from http://www.caac.gov.cn/ XXGK/XXGK/GFXWJ/201601/P020160126526845399237.pdf

Anexo 1, de julho de 2018. Personnel Licensing. Convenio sobre Aviación Civil Internacional (CACI). Retrieved from http://web. shgm.gov.tr/documents/sivilhavacilik/files/pdf/saglik__ birimi/ ICAO_Annex_1_12th.pdf

Anexo 5, de julho 2010. Unidades de medida que se emplearán em las operaciones aéreas y terrestres. Convenio sobre Aviación Civil Internacional (CACI). Retrieved from https://www.anac.gov.ar/anac/web/ uploads/normativa/anexos-oaci/anexo-5.pdf 
Anexo 6, de julho 2016. Operación de aeronaves. Convenio sobre Aviación Civil Internacional (CACI). Retrieved from https://www. anac.gov.ar/anac/web/uploads/normativa/anexos-oaci/anexo-6-parte-i.pdf

Anexo 7, de julho de 2012. Aircraft Nationality and Registration Marks. Convenio sobre Aviación Civil Internacional (CACI). Retrieved from https://www.pilot18.com/wp-content/uploads/2017/10/ Pilot18.com-ICAO-Annex-7-Aircraft-Nationality-and-Registration-Marks.pdf

Anexo 8, de abril de 2005. Airworthiness of Aircraft. Convenio sobre Aviación Civil Internacional (CACI). Retrieved from https://www. theairlinepilots.com/forumarchive/quickref/icao/annex8.pdf

Argyres, N., Bigelow, L., \& Nickerson, J. A. (2015). Dominant designs, innovation shocks, and the follower's dilemma. Strategic Management Journal, 36(2), 216-234. https://doi.org/10.1002/smj.2207

Aulet, B. (2013). Disciplined entrepreneurship: 24 steps to a successful startup. John Wiley \& Sons.

Blank, S. (2017). Why the lean start-up changes everything. Harvard business review. Retrieved from https://edisciplinas.usp.br/pluginfile.php/4138780/mod_resource/content/1/Why\%20the\%20Lean $\% 20$ Start-Up\%20Changes\%20Everything-3.pdf

Blom, J. D. (2010). Unmanned Aerial Systems: a historical perspective. Combat Studies Institute Press. Recuperado de: http://citeseerx. ist.psu.edu/viewdoc/download?doi=10.1.1.261.2109\&rep=rep1\&type $=$ pdf

Cândido, A. K. A. A., da Silva, N. M., \& Paranhos Filho, A. C. (2016). Imagens de alta resolução espacial de veículos aéreos não tripulados (VANT) no planejamento do uso e ocupação do solo. Anuário do Instituto de Geociências - UFRJ 38(1), 147-156. http://dx.doi. org/10.11137/2015_1_147_156

DOC 7300/9, de julho de 2006. Convention on International Civil Aviation. Retrieved from https://www.icao.int/publications/Documents/7300_9ed.pdf

DoD, U. S. (2019). Department of Defense Dictionary of Military and Associated Terms. Joint Publication, 1-376. Retrieved from https:// www.jcs.mil/Portals/36/Documents/Doctrine/pubs/dictionary.pdf

Dung, N. D., \& Rohacs, J. (2018). The drone-following models in smart cities. 2018 IEEE 59th International Scientific Conference on Power and Electrical Engineering of Riga Technical University (RTUCON), Riga, Latvia, 2018, pp. 1-6. http://doi.org/10.1109/RTUCON.2018.8659813

EASA (2020, fevereiro 6). Civil drones (Unmanned aircraft). European Union Aviation Safety Agency. [Site]. Retrieved from https:// www.easa.europa.eu/easa-and-you/civil-drones-rpas
EUROCONTROL (2020, fevereiro 6). Unmanned aircraft systems. Supporting European Aviation. [Site]. Retrieved from https://www. eurocontrol.int/unmanned-aircraft-systems

Finger, M., \& Samwer, O. (1998). America's most successful startups: Lessons for entrepreneurs. Springer Science \& Business Media. GDRD (2020, fevereiro 6). Find country. Global Drone Regulations Database. [Site]. Retrieved from https://droneregulations.info/index. html

Gupta, S. G., Ghonge, M. M., \& Jawandhiya, P. M. (2013). Review of unmanned aircraft system (UAS). International journal of advanced research in computer engineering \& technology (IJARCET), 2(4), 1646-1658. http://dx.doi.org/10.2139/ssrn.3451039

Hair, J., Babin, B., Money, A., \& Samouel, P. (2005). Fundamentos de métodos de pesquisa em administração. Bookman Companhia Ed.

Hodgkinson, D., \& Johnston, R. (2018). Aviation law and drones: Unmanned aircraft and the future of aviation. Routledge.

ICAO (2020) The International Civil Aviation Organization unmanned aircraft Systems Toolkit. Retrieved from https://www.icao.int/ safety/UA/UASToolkit/Pages/Narrative-Regulation.aspx

JARUS (2020, fevereiro 6). Regulations. Joint Authorities for Rulemaking on Unmanned Systems [Site]. Retrieved from http://jarus-rpas.org/regulations

Kaleem, Z., Rehmani, M. H., Ahmed, E., Jamalipour, A., Rodrigues, J. J. P. C., Moustafa, H., \& Guibene, W. (2018). Amateur Drone Surveillance: Applications, Architectures, Enabling Technologies, and Public Safety Issues: Part 1. IEEE Communications Magazine, 56(1), 14-15. http://doi.org/10.1109/mcom.2018.8255731

Koche, J. C. (2011). Fundamentos de metodologia científica: teoria da ciência e iniciação à pesquisa. Editora Vozes.

Koche, J. C. (2016). Fundamentos de metodologia científica. Editora Vozes.

Lai, W. H., Lai, Y. C., Lan, Z. S., Lin, H. H., \& Ho, W. K. (2018). Development of an Internet of Things System Based on Unmanned Aerial Vehicles for the Application of Smart Security from Sky. Journal of Aeronautics, Astronautics and Aviation, 50(2), 135-146. http://doi. org/10.6125/JoAAA.201806_50(2).03

Lijphart, A. (1971). Comparative politics and the comparative method. American political science review, 65(3), 682-693. https://doi. org/10.2307/1955513

Liu, Q., Peng, P. H., Wang, Y. K., Xu, P., \& Guo, Y. M. (2019). Microclimate regulation efficiency of the rural homegarden agroforestry system in the Western Sichuan Plain, China. Journal of Mountain Science, 16(3), 516-528. https://doi.org/10.1007/s11629-018-5112-1 
Mack, E., \& Mayer, H. (2015). The evolutionary dynamics of entrepreneurial ecosystems. Urban Studies, 53(10). https://doi. org/10.1177/0042098015586547

Manuella, V. R. (2016). Ciência em comunicação no Youtube brasileiro: Canal Manual do Mundo. 12 Interprogramas de mestrado. Faculdade Cásper Líbero. Retrieved from https://casperlibero.edu. br/wp-content/uploads/2017/03/Manuella-Reale-PUCSP-Trabalho-Completo.pdf

Molin, J. P. (2017). Agricultura de precisão: Números do mercado brasileiro. Universidade de São Paulo, Departamento de Engenharia de Biossistemas. São Paulo: Escola Superior de Agricultura "Luiz de Queiroz". Retrieved from http://www.agriculturadeprecisao.org.br/ wp-content/uploads/2019/08/BT_3.pdf

Mrva, D. (2017). Použití Bezpilotních Prostředků Islámským Státem: Povaha hrozby. Univerzita Obrany. Ustav Strategickych Studii. Obrana a Strategie, 2017(2), 83-99. http://dx.doi.org/10.3849/18027199.17.2017.02.083-100

Nunes, G. C., Nascimento, M. C. D., \& de Alencar, M. A. C. (2016). Pesquisa científica: conceitos básicos. Id on-line revista multidisciplinar e de psicologia, 10(29), 144-151. https://doi.org/10.14295/idonline.v10i1.390

Oliveira, T. P. A., Pantoja, M. J., \& Brisola, M. V. (2016). Plano ABC: Contribuições Teóricas para o Novo Paradigma da Agropecuária e uma Proposta de Avaliação. Revista em Agronegócio e Meio Ambiente, 9(3), 719. https://doi.org/10.17765/2176-9168.2016v9n3p719-740

Pecharromán, J. M., \& Veiga, R. (2019). Estudo Sobre a Indústria Brasileira e Europeia de Veículos Aéreos Não Tripulados. [S. 1.], 2016. Retrieved from http://www.mdic.gov.br/images/publicacao_DRONES-20161130-20012017-web.pdf
Picken, J. C. (2017). From startup to scalable enterprise: Laying the foundation. Business Horizons, 60(5), 587-595. https://doi.org/10.1016/j.bushor.2017.05.002

Raparelli, E., \& Bajocco, S. (2019). A bibliometric analysis on the use of unmanned aerial vehicles in agricultural and forestry studies. International Journal of Remote Sensing, 40(24) 9070-9083. https://doi. org/10.1080/01431161.2019.1569793

Stocker, C., Bennett, R., Nex, F., Gerke, M., \& Zevenbergen, J. (2017). Review of the current state of UAV regulations. Remote sensing, 9(5), 459. https://doi.org/10.3390/rs9050459

Valavanis, K. P., \& Kontitsis, M. (2007). A historical perspective on unmanned aerial vehicles. In Advances in Unmanned Aerial Vehicles (pp. 15-46). Intelligent Systems, Control and Automation: Science and Engineering, vol 33. Springer, Dordrecht. https://doi. org/10.1007/978-1-4020-6114-1_2

Wagner, M. (2015). Unmanned Aerial Vehicles. Max Planck Encyclopedia of Public International Law, Rüdiger Wolfrum, ed., Oxford University Press, Forthcoming; University of Miami Legal Studies Research Paper No. 15-12. Retrieved from https://papers.ssrn.com/sol3/ papers.cfm?abstract_id $=2584652$

Watts, A. C., Ambrosia, V. G., \& Hinkley, E. A. (2012). Unmanned Aircraft Systems in Remote Sensing and Scientific Research: Classification and Considerations of Use. Remote Sensing, 4(6), 1671-1692. http://dx.doi.org/10.3390/rs4061671

Weber, L. (2017). International Civil Aviation Organization. Kluwer Law International BV. 


\section{Appendix 1}

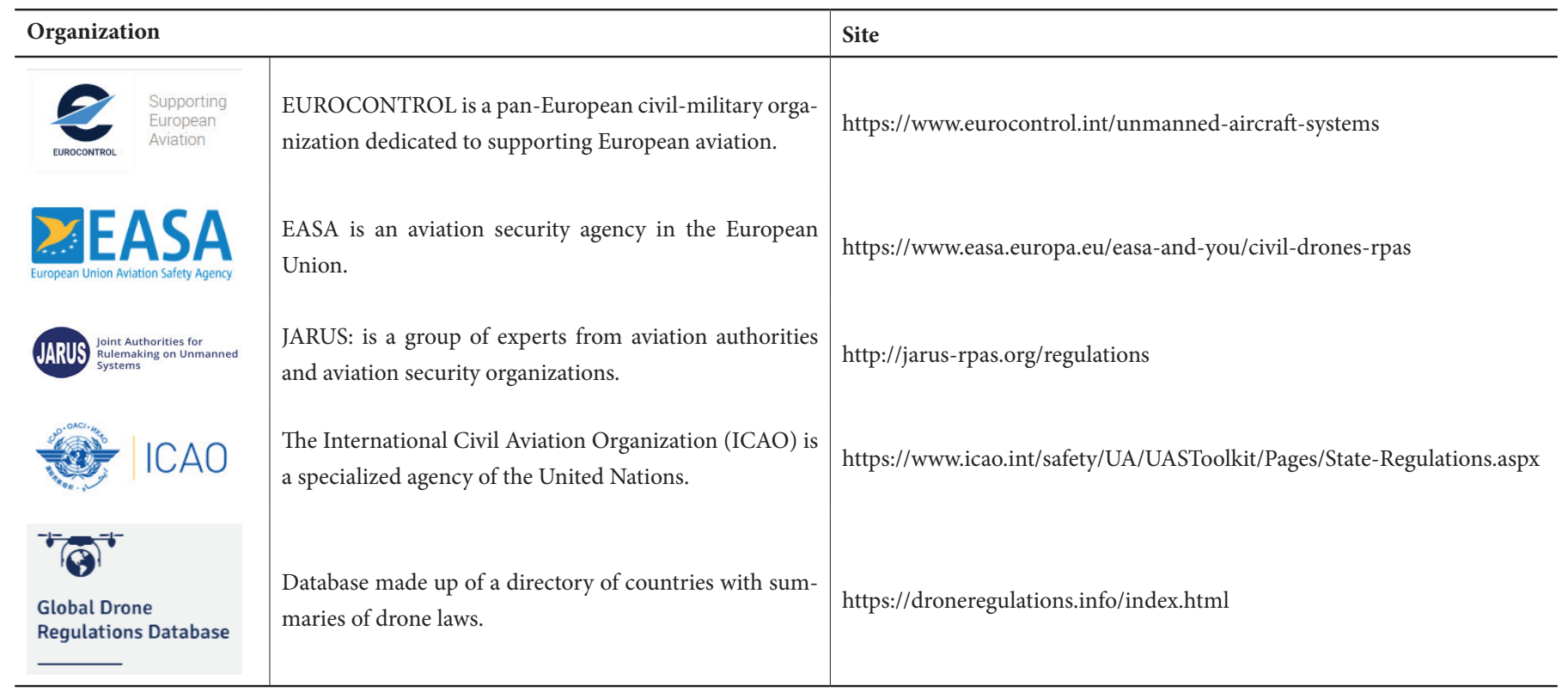

Source: Prepared by the author (2020).

Appendix 1. List of organizations collaborating with unmanned aircraft regulations.

\section{Appendix 2}

\begin{tabular}{|c|c|c|}
\hline Countries & EASA & ICAO \\
\hline Germany & Member of the Board of Directors - EASA Representative Office & Member \\
\hline Saudi Arabia & Work arrangement & Member \\
\hline Austria & Member of the board of directors & Member \\
\hline Belgium & Member of the Board of Directors - EASA Representative Office & Member \\
\hline Brazil & Bilateral agreement - Technical cooperation project & Member \\
\hline South Korea & Memorandum of Understanding & Member \\
\hline Denmark & Member of the board of directors & Member \\
\hline Spain & Member of the board of directors & Member \\
\hline United States & Work provision - Bilateral agreement - EASA Representative Office & Member \\
\hline France & Member of the board of directors & Member \\
\hline Israel & Work arrangement - Technical cooperation project & Member \\
\hline Italy & Member of the board of directors & Member \\
\hline Japan & Work arrangement & Member \\
\hline Malaysia & Technical cooperation project & Member \\
\hline Norway & Member of the board of directors & Member \\
\hline Netherlands & Member of the board of directors & Member \\
\hline Russia & Work arrangement & Member \\
\hline Taiwan & Work arrangement & Not applied \\
\hline Turkey & Work arrangement - Technical cooperation project & Member \\
\hline
\end{tabular}

Source: Prepared by the author (2020).

Appendix 2. EASA and ICAO membership. 


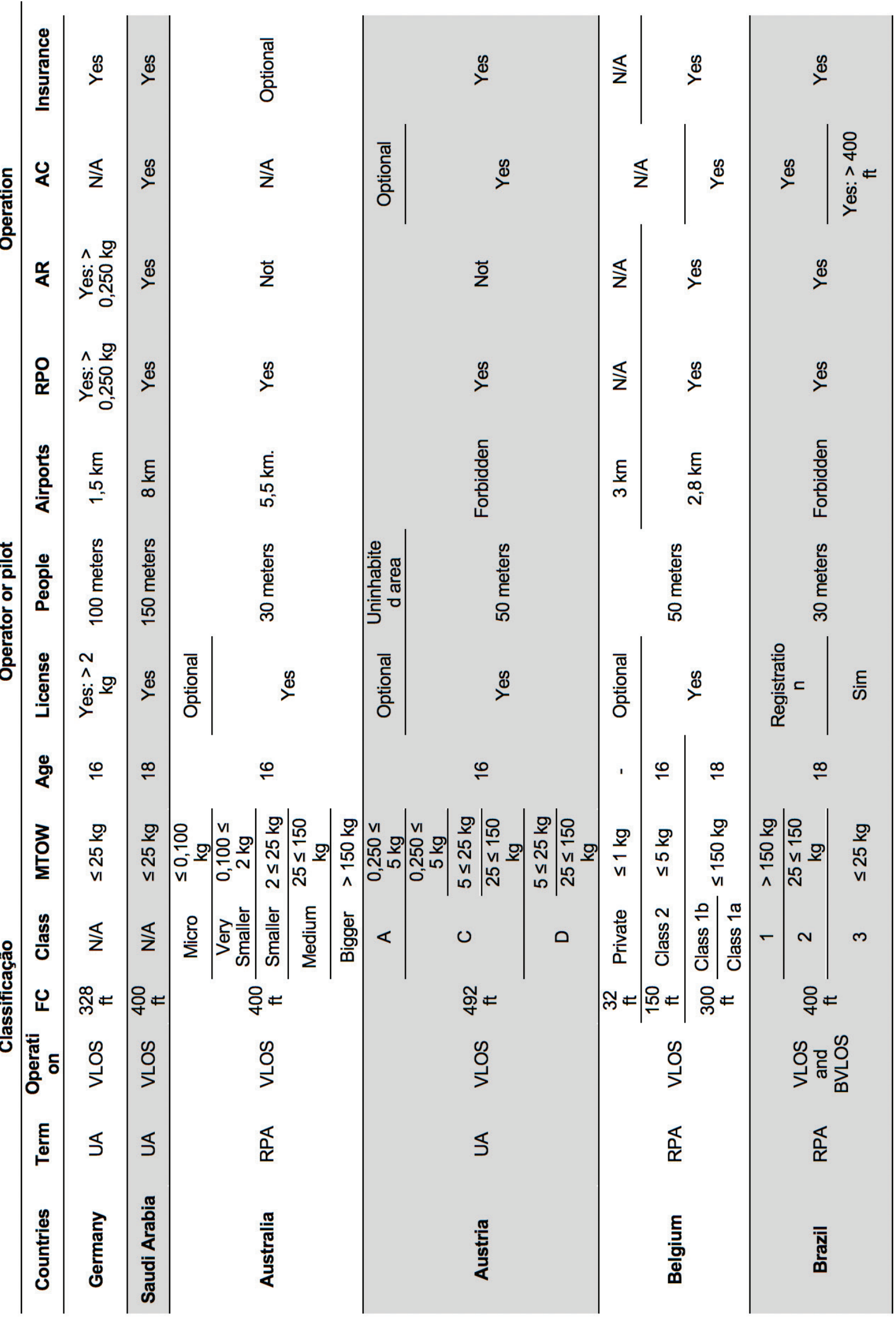




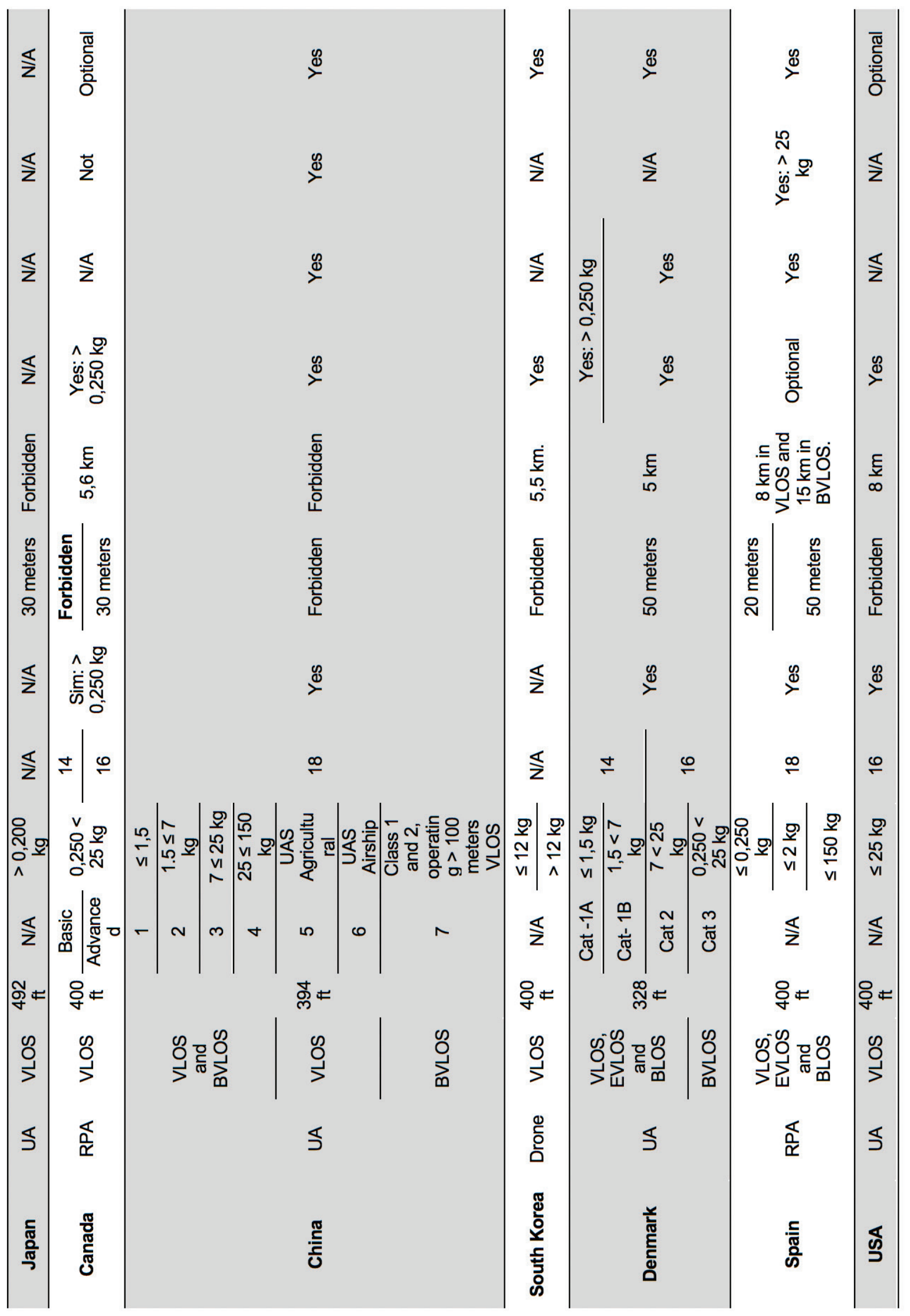




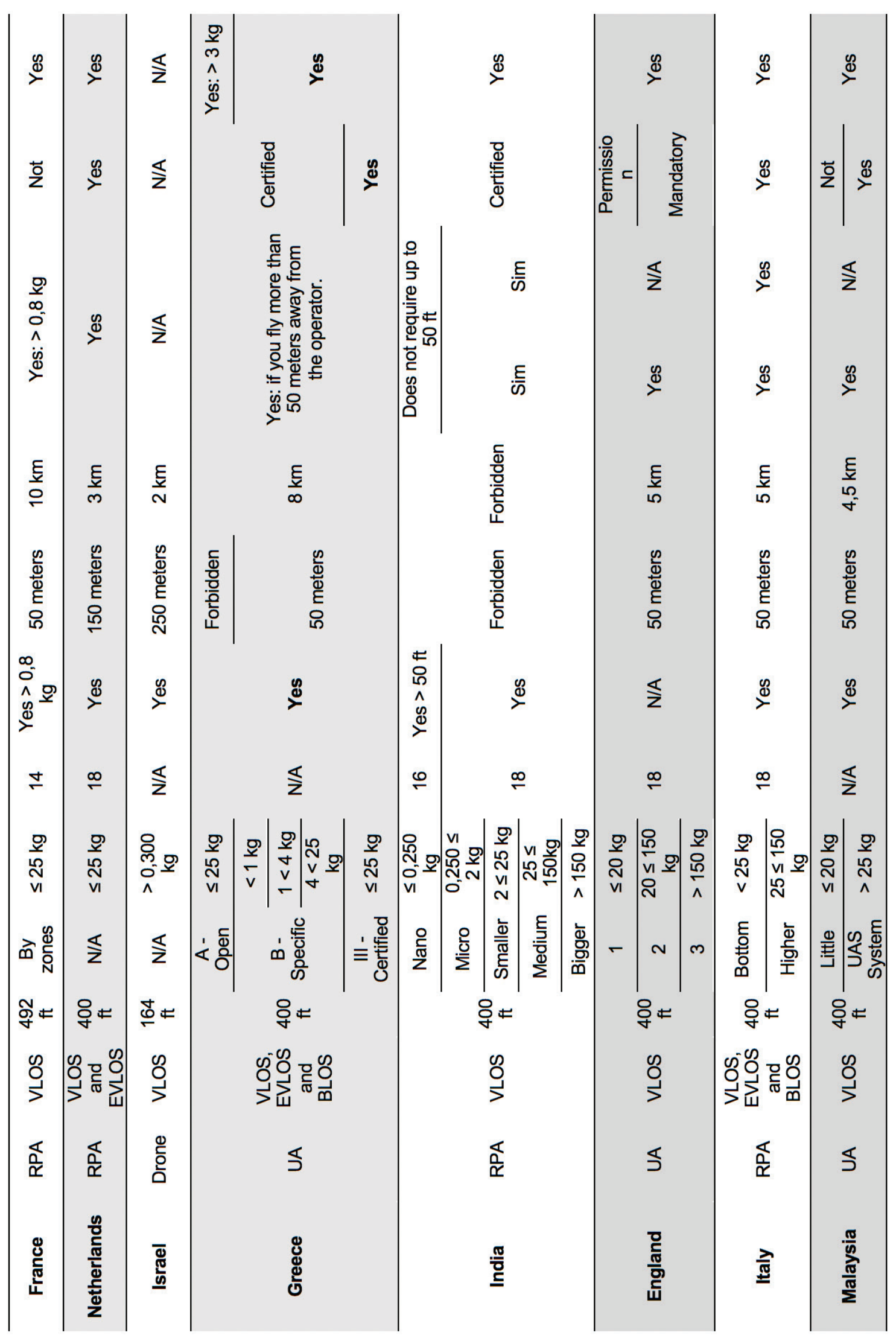




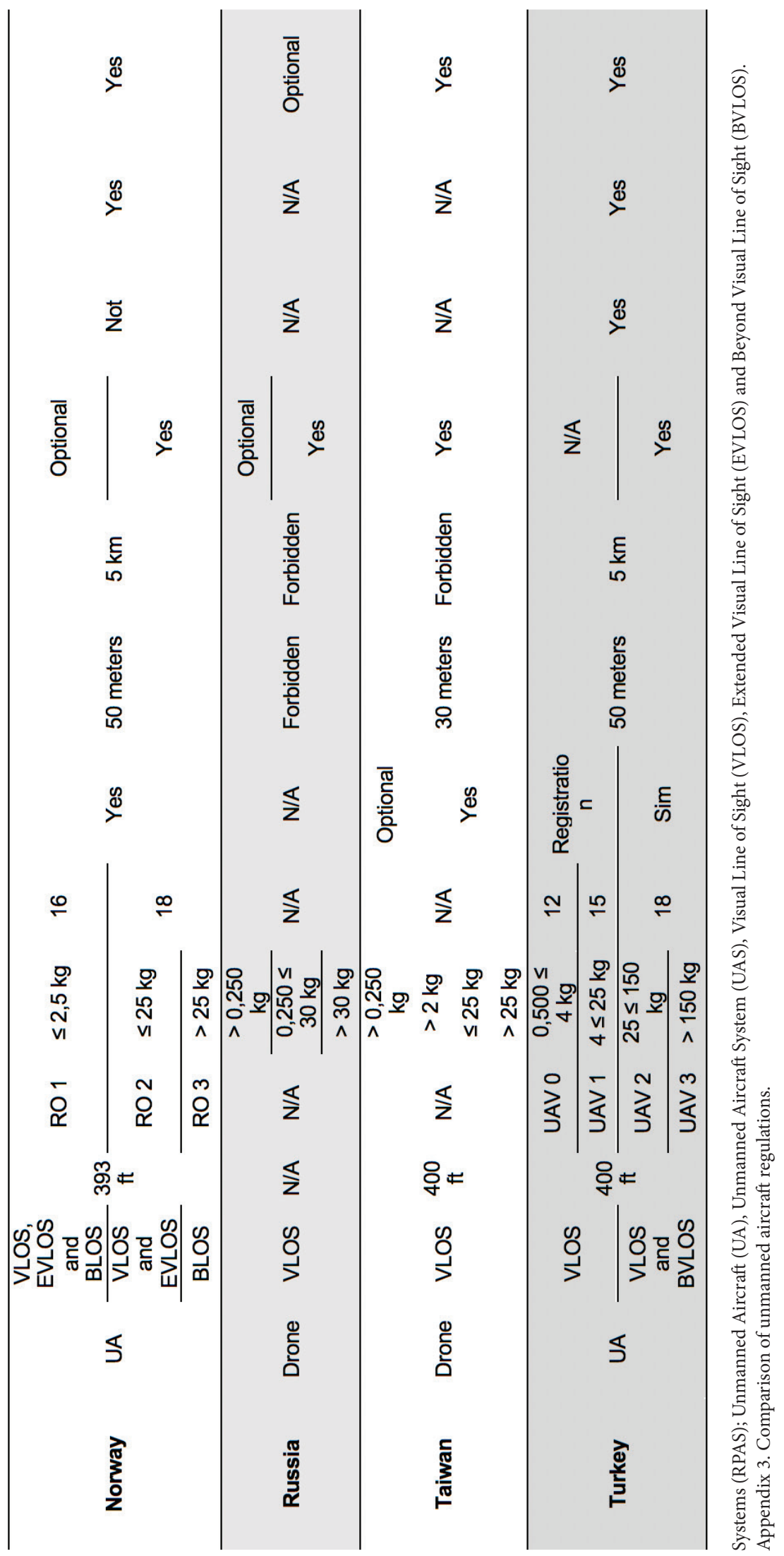


